\title{
Perspective
}

\section{Conservation of bats in China: problems and recommendations}

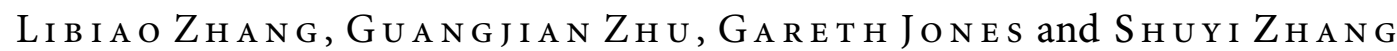

\begin{abstract}
Bat populations in China appear to have decreased considerably in the last 30 years. Four reasons may have been responsible: (1) Cave exploitation for tourism has changed the atmosphere and temperature in caves, disturbing bats directly. (2) Extensive pesticide use has resulted in bioaccumulation in bats, reducing their survival. (3) Many old buildings were demolished during urbanization, reducing the availability of suitable roost sites. (4) People often include bats in their diet, and bats are served in restaurants. We make recommendations for improving bat conservation in China. Education programmes about bat conservation should be provided for adults and schoolchildren, and laws for protecting bats need to be enacted and enforced. The roosting sites of bats should be protected comprehensively, and pesticide use should be regulated.
\end{abstract}

Keywords Bat conservation, bushmeat, cave tourism, China, old buildings, pesticide use, roost.

O hina has a rich bat fauna, with $>100$ species described (Smith \& Xie, 2008), and taxonomic research on bats has increased in the last 2 decades. Three new species have been described (Zhang et al., 2007; Feng et al., 2008; Wu et al., 2008) and the distribution of seven others revised substantially (He \& Yang, 1991; Zhao et al., 2002; Zhang et al., 2004; Zhang L.B. et al., 2005; Zhang J.S. et al., 2005; Feng et al., 2006; Jiang et al., 2008; Tan et al., 2009). However, decreases in bat populations have become a matter of concern. Here we review the main problems that currently affect bats in China, including cave exploitation for tourism, pesticide use, loss of old buildings and use for food, and we make appropriate recommendations.

Cave tourism in China, especially in the south, has burgeoned. The effect of tourism on the environment in caves has been studied in China and elsewhere (Cigna \& Forti, 1988; Song et al., 1997). The flow of visitors causes fluctuations in carbon dioxide content and temperature,

Libiao Zhang and Guangjian Zhu Guangdong Entomological Institute, Guangzhou, 510260 China.

Gareth Jones School of Biological Sciences, University of Bristol, Bristol, UK

SHUYi Zhang (Corresponding author) School of Life Sciences, East China Normal University, Shanghai, 200062 China. E-mail syzhang@bio.ecnu. edu.cn and cave topography and dimensions affect the accumulation and diffusion of the gas, disturbing bats directly (Song et al., 2000). On 2 May 2001, for example, the maximum $\mathrm{CO}_{2}$ content increased from 1,000 to 7,000 ppm in the chamber in Baiyun Cave, Hebei, after c. 3,00o people visited for 5 hours, and the temperature increased from 16.8 to $19.6^{\circ} \mathrm{C}$ (Song et al., 2004). In the last 20 years caves have been exploited for tourism and caving, without prior environmental impact assessments having been conducted (Song et al., 2004). The effects of disturbance on bats and other cave fauna have seldom been studied in China. Lighting schemes have been installed for visitors without any consideration of the effects on bats and other cave animals, paths have been constructed, and gates at cave entrances for managing visitors are often unsuitable for flying bats to negotiate. The population of fruit bat Rousettus leschenaulti in Yiling Cave in Guangxi Province, for example, decreased from c. 5,000 to $<2,000$ after cave tourism was implemented in 1993 (L. Zhang \& S. Zhang, pers. obs.).

Based on our surveys of bats in China, combined with enquiries to local people, we estimate that the bat population may have decreased by $60 \%$ in the last 30 years. Mortality of bats from pesticides has been well documented (Luckens \& Davis, 1964; Bennett \& Thies, 2007), although the effects of sub-lethal levels of pesticide on bat metabolism and survival has been little studied (Swanepoel et al., 1999). The largest bat colony (of the mollossid Chaerephon plicata) known in China, at Feishu Cave, Guangxi Province, is estimated to have decreased from 1 million to 100,000 in the past 30 years (L. Zhang, pers. obs.). Local people near Feishu Cave told us that heavy crop yields could be obtained with little pesticide use 30 years ago, whereas more and more pesticides now have to be used to ensure similar yields. It is likely that the pests were formerly controlled by the large population of $C$. plicatus but that the increased use of pesticides caused the decrease of the bat population as a result of bioaccumulation (Schnoor, 1981). Studies on pesticide levels in these bats would be illuminating.

Availability of suitable roost sites may limit bat distribution and abundance, and protection of roost sites is essential for bat conservation. Many bat species roost in old buildings (Kunz \& Lumsden, 2003), which they select as maternity roosts (Williams \& Brittingham, 1997) or hibernacula (Whitaker \& Gummer, 1992). The advantages for bats 
roosting in buildings (lower predation risk, earlier births, faster juvenile growth rates and increased energy savings) lead to greater long-term reproductive success (Lausen \& Barclay, 2006). During urbanization many old buildings were demolished and their replacements are not suitable as bat roosts, and in many areas in China no houses suitable for roosting bats remain. Little attention is paid to bat conservation during planning, and thus bats are not included in impact assessments for construction of new buildings.

Bats provide important ecosystem services, pollinating plants, dispersing seeds and controlling pests. However many people in China regard bats as vermin because some species feed on economically important fruits, such as longan and litchi. Bats are also regarded as nefarious animals because they fly in the dark. Before the emergence of the SARS virus many restaurants in Guangzhou and other cities in south China offered bats, and live bats were also sold in markets (Mickleburgh et al., 2009; L. Zhang \& S. Zhang, pers. obs.). In some remote villages our surveys have repeatedly revealed that local people capture wild bats to eat, to meet their protein requirements (L. Zhang \& S. Zhang, pers. obs.). We have also found bamboo wattles, used to kill bats, in caves (L. Zhang \& G. Zhu, pers. obs.).

There are additional factors causing decreases of bat populations in China. Many forests were destroyed during the Cultural Revolution (1966-1976) and vast steel-making and iron-smelting facilities were established, resulting in the loss of many roosting sites and foraging areas. Recently, many small paper mills have been built, resulting in the clear-cutting of forests and their replacement with the fast growing eucalypts that are preferred by the mills (Zhang, 2008). We have found that many limestone hills excavated to make cement have lost their bat-roosting caves. No bat species are included in the lists of wildlife under special state protection (1989 Law of the People's Republic of China on the Protection of Wildlife), and no nature reserves protect bat species or their roost sites. Access to caves in which bats roost is unrestricted.

To prevent further declines of bat populations in China we make the following recommendations. (1) Education programmes about the importance of bats in providing ecosystem services should be available for adults and schoolchildren; the people and the government should be provided with more information so that they can participate in conservation of bats rather than eat them. (2) Local and national governments should enact laws to protect bats; the addition of threatened bat species to the lists of wildlife under special state protection in China would improve people's perception of bats. (3) Roosting sites should be protected, even from researchers, so that bats are not disturbed, especially during critical periods such as pregnancy, lactation and hibernation; exploitation of caves, demolition of old buildings, and quarrying of limestone hills should be subject to environmental impact assessments before work is conducted. (4) Farmers should use safer pesticides, both for their own health and the benefit of bats; this is especially important for the economy of people living in remote villages and for bats in such areas.

Some advances have already been made. Research on bats is now taking place in several Chinese universities. An award from the UK Darwin Initiative was important in developing a research and education centre to promote bat conservation close to Beijing. The Centre has a display area, dormitories, a kitchen and dining room, experimental rooms, bat housing facilities and a large flight area that has hosted a colony of fishing bats Myotis ricketti. The Centre has hosted postgraduate students and groups of schoolchildren. A bat research group has been established at the Institute of Zoology, Chinese Academy of Sciences in Beijing, at East China Normal University in Shanghai, and at Guangdong Entomological Institute in Guangzhou, under the direction of SZ. During tenure of the Darwin Initiative research was carried out on the taxonomic status of small horseshoe bats in Asia (Li et al., 2006), the diet, echolocation calls and genetics of the endemic Myotis pequinius (Jones et al., 2006), the large bat Ia io, discovered to feed extensively on birds by capturing them in flight

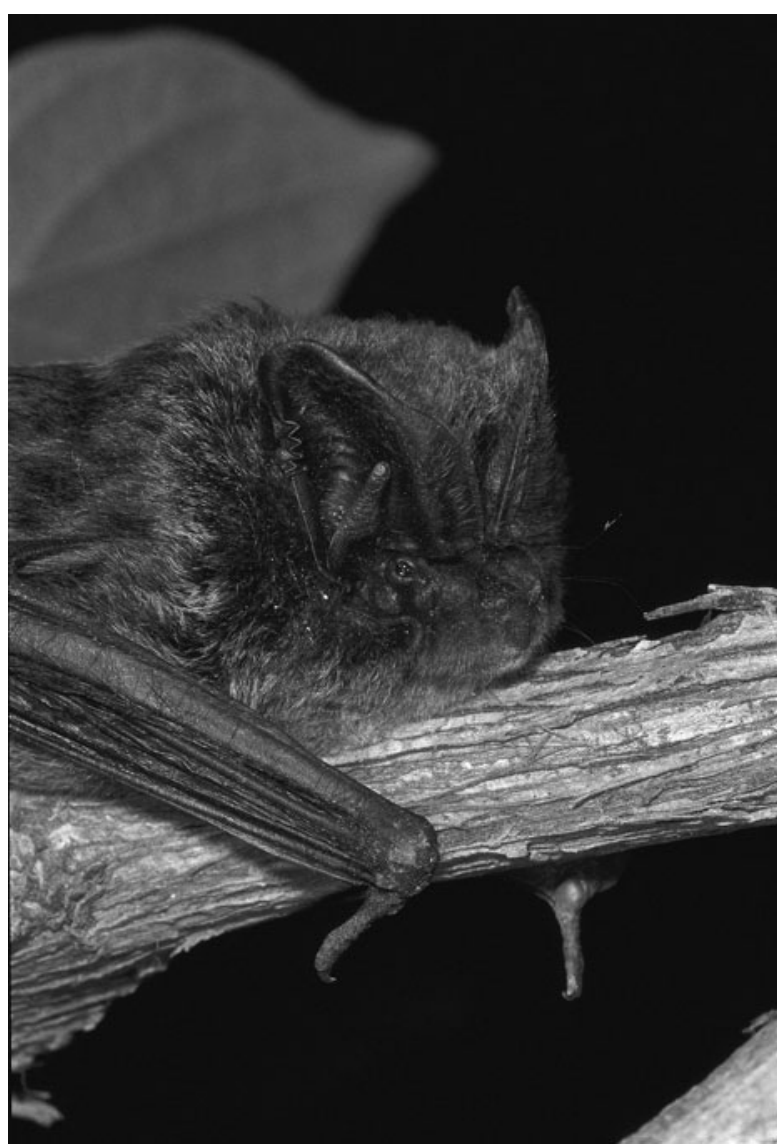

Plate 1 Barbastella beijingensis, a recently described bat species (Zhang et al., 2007), occurs in Fangshan, Beijing. 
(Thabah et al., 2007), genetic variation in greater horseshoe bats across their range, showing extensive genetic divergence of Chinese bats and the occurrence of two lineages with different echolocation calls in China (Rossiter et al., 2007), and description of a new species, Barbastella beijingensis, which was first captured near the Darwin Initiative Centre (Plate 1; Zhang et al., 2007).

A web site describing the bat fauna of China was developed under the Darwin Initiative (Bats in China, 2009). The site includes photographs, range maps, echolocation call recordings and a bibliography covering 72 species. Articles about bats are appearing in the Chinese popular press and on national television. A guide for teachers about bat conservation is available in Hong Kong. Local people in Guangxi are being educated about the conservation of bats in the region's bamboo forests (Zhang, 2008). If these and other initiatives can be developed further there is yet hope for the conservation of bats in China despite the intense pressures associated with industrialization, urbanization and habitat loss.

\section{Acknowledgements}

We thank many people for comments, in particular Xicai Yuan, Tiyu Hong, Wei Zhang, Min Tan, Jianping Ye and Jinshuo Zhang, and Paul Racey, who kindly commented on an earlier draft of the article. This work was supported by grants from National Natural Science Foundation of China (NSFC, No. 30800102) to LB Zhang, the Darwin Initiative (14-008) to G Jones, and the Key Construction Program of the National "985" Project to SY Zhang.

\section{References}

BATS IN CHINA (2009) Http://www.bio.bris.ac.uk/research/bats/ Chinabats/index.htm [accessed 6 February 2009].

Bennett, B.S. \& Thies, M.L. (2007) Organochlorine pesticide residues in guano of Brazilian free-tailed bats, Tadarida brasiliensis Saint-Hilaire, from East Texas. Bulletin of Environmental Contamination and Toxicology, 78, 191-194.

Cigna, A.A. \& Forti, P. (1988) The environmental impact assessment of a tourist cave. In Cave Tourism, Proceedings of the International Symposium for on 17oth Anniversary of Postojnska Jama (ed. A. Kranjc), pp. 29-38. Karst Research Institute ZRCSAZO, Postojna, Slovenia.

FENG, Q., JiAnG, X.L., LI, S. \& WANG, Y.X. (2006) A new record: genus Megaerops and its two species of bat in China (Chiroptera, Pteropodidae). Acta Zootaxonomica, 31, 224-230.

FENG, Q., LI, S. \& WANG, Y.X. (2008) A new species of bamboo bat (Chiroptera: Vespertilionidae: Tylonycteris) from south-western China. Zoological Science, 25, 225-234.

He, X.R. \& YANG, B.L. (1991) A new record of Chinese bat from Kunming of Yunnan - Pteropus lylei K. Andersen. Acta Theriologica Sinica, 11, 71-72.

JiAnG, T.L., LiU, Y. \& FenG, J. (2008) A new Chinese record species. Acta Zootaxonomica Sinica, 33, 212-216.

Jones, G., Parsons, S., ZhanG, S., Stadelmann, B., Benda, P. \& Ruedi, M. (2006). Echolocation calls, wing shape, diet and phylogenetic diagnosis of the endemic Chinese bat Myotis pequinius. Acta Chiropterologica, 8, 451-464.

Kunz, T.H. \& Lumsden, L. (2003) Ecology of cavity and foliage roosting bats. In Bat Ecology (eds T.H. Kunz \& M.B. Fenton), pp. 3-89. The University of Chicago Press, Chicago, USA.

Lausen, C.L. \& Barclay, R.M. (2006) Benefits of living in a building: big brown bats (Eptesicus fuscus) in rocks versus buildings. Journal of Mammalogy, 87, 362-370.

Li, G., Jones, G., Rossiter, S.J., Chen, S.F., Parsons, S. \& $Z_{\text {HANG }}$ S. (2006). Phylogenetics of small horseshoe bats from East Asia based on mitochondrial DNA sequence variation. Journal of Mammalogy, 87, 1234-1240.

Luckens, M.M. \& Davis, W.H. (1964) Bats: sensitivity to DDT. Science, 146, 948.

Mickleburgh, S., Waylen, K. \& Racey, P. (2009) Bats as bushmeat: a global review. Oryx, 43, 217-234.

Rossiter, S.J., Benda, P., Dietz, C., Zhang, S. \& Jones, G. (2007) Range-wide phylogeography in the greater horseshoe bat inferred from microsatellites: implications for population history, taxonomy and conservation. Molecular Ecology, 16, 4699-4714.

Schnoor, J.L. (1981) Fate and transport of dieldrin in Coralville reservoir: residues in fish and water following a pesticide ban. Science, 211, 840-842.

Smith, A.T. \& Xie, Y. (2008) A Guide to the Mammals of China. Princeton University Press, Princeton, USA.

SonG, L.H., Wang, J., LianG, F.Y., Wei, X.N. \& LiN, J.S. (2004) Effect of human and natural factors on the environment of show caves. Carsologica Sinica, 23, 19-27.

Song, L.H., Wei, X.N. \& Liang, F.Y. (2000) The influences of cave tourism on $\mathrm{CO}_{2}$ and temperature in Baiyun Cave, Hebei, China. International Journal of Speleology, 29, 77-87.

SonG, L.H., YANG, J., Lin, J., WANG, L., YU, J., ZhanG, R. \& TANG, M. (1997) The case study on the effect of $\mathrm{CO}_{2}$ in cave atmosphere on stability of speleotherm scenery in Yaolin Cave, Zhejiang province, China. The Journal of Chinese Geography, $7,26-36$.

Swanepoel, R.E., Racey, P.A., Shore, R.F. \& Speakman, J.R. (1999) Energetic effects of sub-lethal exposure to lindane on pipistrelle bats (Pipistrellus pipistrellus). Environmental Pollution, $104,169-177$.

Tan, M., ZhU, G.J., Hont, T.Y., Ye, J.P. \& ZHang, L.B. (2009) New record of a bat species from China, Hipposideros cineraceus (Blyth, 1853). Zoological Research, 30, 204-208.

Thaвah, A., Li, G., Wang, Y., Liang, B., Hu, K., Zhang, S. \& Jones, G. (2007). Diet, echolocation calls and phylogenetic affinities of the great evening bat Ia io (Vespertilionidae): another carnivorous bat. Journal of Mammalogy, 88, 728-735.

Whitaker Jr, J.O. \& Gummer, S.L. (1992) Hibernation of the big brown bat, Eptesicus fuscus, in buildings. Journal of Mammalogy, $73,312-316$.

Williams, L.M. \& Brittingham, M.C. (1997) Selection of maternity roosts by big brown bats. Journal of Wildlife Management, 61, 359-368.

Wu, Y., Mотокаwa, M. \& Harda, M. (2008) A new species of horseshoe bat of the genus Rhinolophus from China (Chiroptera: Rhinolophidae). Zoological Science, 25, 438-443.

Zhang, J.S., Han, N.J., Jones, G., Lin, L.K., ZhanG, J.P., Zhu, G.J. et al. (2007) A new species of Barbastella (Chiroptera: Vespertilionidae) from North China. Journal of Mammalogy, 88, 1393-1403.

Zhang, J.S., Zhang, L.B., ZhaO, H.H., LiAnG, B. \& ZhanG, S.Y. (2005) First record of Chinese bats: Rhinolophus stheno. Chinese Journal of Zoology, 40, 96-98. 
ZHANG, L.B. (2008) Conserving China's tiniest bats - sugar cane and paper threaten bamboo bats. Bats, 26, 1-3.

ZHANG, L.B., Long, Y.C., ZHANG, J.S. \& ZHANG, S.Y. (2005) New record of bat species - Rhinolophus marshalli from China. Acta Theriologica Sinica, 25, 77-80.

Zhang, L.B., Zhang, J.S., LiAnG, B. \& ZHANG, S.Y. (2004) New record of a bat species from China, Myotis hasseltii (Temminck, 1840). Zoological Research, 25, 556-559.

Zh ао, H.H., Zhang, S.Y., Zhou, J. \& Liu, Z.M. (2002) New record of bats from China: Rhinolophus paradoxolophus. Acta Theriologica Sinica, 22, 74-76.

\section{Biographical sketches}

LibiaO $Z_{\text {HANG }}$ researches the ecology and conservation biology of bats, especially bamboo bats. GUANGJIAN $Z_{H U}$ works on the behavioural ecology of bats, focusing on the conservation status of fruit bats. GARETH JONEs leads a research group studying echolocation, molecular ecology and conservation biology of bats. He has studied bats in six continents and has worked with Shuyi Zhang in China since 2001. SHUYI ZHANG leads a large research group of about 40 staff and students, studying behavioural ecology, molecular ecology, molecular evolution and conservation biology of bats, and virus-bat co-evolution. 